\title{
EFEKTIVITAS PENYEMBUHAN LUKA TERBUKA PADA KELINCI DARI FORMULASI SALEP EKSTRAK ETANOL DAUN BABADOTAN
}

(Ageratum conyzoides L.)

\author{
Ferry Effendi' ${ }^{*}$., Halimatussa' diyah ${ }^{1}$., Sri Helmina ${ }^{1}$ \\ 1. Program Studi Farmasi Sekolah Tinggi Teknologi Industri dan Farmasi Bogor
}

Korespondensi: $\underline{\mathrm{f} 312 \mathrm{ye} @ \text { gmail.com }}$

\begin{abstract}
ABSTRAK
Ageratum conyzoides L. yang dikenal dengan nama daun babadotan adalah tanaman obat yang telah digunakan untuk mengobati berbagai penyakit, termasuk obat luka terbuka. Penelitian sebelumnya menyatakan bahwa ekstrak etil asetat daun babadotan memberikan efek penyembuhan yang nyata (bermakna) pada luka terbuka yaitu pada konsentrasi $40 \%$ dan $80 \%$. Berdasarkan hal itu, dilakukan penelitian pendahuluan yang bertujuan untuk mengetahui efektivitas sediaan salep ekstrak etanol daun babadotan (Ageratum conyzoides L.) terhadap penyembuhan luka terbuka pada kelinci. Jenis penelitian ini ialah eksperimen laboratorium. Simplisia serbuk daun babadotan diekstraksi dengan menggunakan metode maserasi. Salep ekstrak etanol daun babadotan dibuat dalam 5 konsentrasi yaitu $30 \%, 35 \%, 40 \%, 45 \%$ dan 50\%. Pada pengujian salep dilakukan uji organoleptik, uji homogenitas, uji daya sebar dan uji $\mathrm{pH}$. Uji efektivitas penyembuhan luka terbuka menggunakan 7 kelompok, yaitu kontrol negatif (tanpa perlakuan), kontrol positif (povidone iodine), salep ekstrak etanol daun babadotan (SEDB) 30\%, SEDB 35\%, SEDB 40\%, SEDB 45\%, SEDB 50\% terhadap 3 kelinci putih dengan berat 3-3.5 kg dan panjang luka $1.5 \mathrm{~cm}$, dilakukan sampai hari ke-8. Data diolah secara statistik menggunakan One Way ANOVA (Analisis Of Variant). Hasil penelitian ini menunjukan bahwa SEDB $40 \%, 45 \%$ dan $50 \%$ memberikan efek penyembuhan terhadap luka terbuka pada kelinci, efek yang hampir mirip dengan kontrol positif yaitu SEDB dengan konsentrasi 45\%, SEDB yang memberikan efek paling baik yaitu salep pada konsentrasi $50 \%$.
\end{abstract}

Kata kunci : Ageratum conyzoides L. Ekstrak etanol daun babadotan, salep, luka, kelinci.

\section{ABSTRACT}

Conyzoides ageratum L. known as babadotan leaves is herbal medicine which been used to threat a variety of diseases, including drugs open wounds. Previous research states that the ethyl acetate extract of babadotan leaves real healing effect (significant) on an open wound that is at a concentration of $40 \%$ and $80 \%$. Based on that, do preliminary research aims to determine the effectiveness of the ointment preparations ethanolic extract of babadotan leaves (Ageratum conyzoides L.) against the open wound healing in rabbits. This type of research is a laboratory experiment. Simplicia babadotan leaf powder extracted using maceration methods. Babadotan leaf ethanolic extract ointment made within 5 concentration that is $30 \%, 35 \%, 40 \%, 45 \%$ and $50 \%$. On testing ointment organoleptic test, homogeneity test, dispersive power test and $\mathrm{pH}$ test. Test the effectiveness of healing of open wounds using seven groups: negative control (without treatment), positive control (povidone iodine), ointments ethanol extract of babadotan leaves (SEDB) 30\%, 35\% SEDB, SEDB 40\%, SEDB 45\%, 50\% SEDB against 3 white rabbits weighing $3-3.5 \mathrm{~kg}$ and a length of $1.5 \mathrm{~cm}$ open wound, was done and observed until 8 days. The data were processed statistically using One Way ANOVA (Analysis Of Variant). These results indicate that leaf ethanolic extract ointment babadotan $40 \%, 45 \%$ and $50 \%$ has a healing effect on open wounds in rabbits, the effect is almost similar to the positive control which leaves extract ointment babadotan with a concentration of $45 \%$, while the ointment babadotan leaf extracts that provide the most excellent effect that an ointment at a concentration of $50 \%$.

Keywords: Ageratum conyzoides L. Ethanolic extract of babadotan leaves, ointments, wound, rabbits. 


\section{PENDAHULUAN}

Pemanfaatan bahan alam yang berasal dari tumbuhan sebagai obat tradisional telah lama dilakukan oleh masyarakat Indonesia untuk menangani berbagai masalah kesehatan. Hal ini cukup menguntungkan karena bahan bakunya mudah didapat atau dapat ditanam di pekarangan sendiri, relatif murah dan dapat diramu sendiri di rumah. Tumbuhan obat sudah sejak lama dimanfaatkan oleh masyarakat dalam upaya penyembuhan dan pencegahan penyakit, peningkatan daya tahan tubuh serta mengembalikan kebugaran. Seperti diketahui bahwa Indonesia adalah negara terbesar kedua setelah Brazil dalam kekayaan keanekaragaman hayati atau merupakan negara terbesar pertama apabila biota laut diperhitungkan. Dari sekitar 30 ribu jenis tumbuhan yang ada di Indonesia tersebut, lebih dari 1000 jenis telah dimanfaatkan untuk pengobatan. Hal ini menunjukkan bahwa Indonesia sangat kaya akan bahan obat yang berasal dari alam. [1]

Babadotan (Ageratum conyzoides L.) merupakan tanaman yang tergolong ke dalam tumbuhan terna semusim, tumbuh tegak atau bagian bawahnya berbaring, tingginya sekitar $30-90 \mathrm{~cm}$ dan bercabang. Batangnya berbentuk bulat dan berambut panjang, jika menyentuh tanah akan mengeluarkan akar. Daun bertangkai, letaknya saling berhadapan dan bersilang. Helaian daun umumnya utuh, warna hijau sampai hijau tua atau hijau kelabu, berbentuk bundar telur, panjang $3 \mathrm{~cm}$ sampai 4 $\mathrm{cm}$, lebar $1 \mathrm{~cm}$ sampai $2.5 \mathrm{~cm}$, ujung daun runcing, pangkal daun tumpul, pinggir daun beringgit, tangkai daun $0.5 \mathrm{~cm}$ sampai $3 \mathrm{~cm}$, tulang daun menyirip. [2]

Daun dan bunga babadotan (Ageratum conyzoides L.) mengandung glikosida, tanin, alkoloid, resin, saponin, flavonoida, terpen polifenol. Didaunnya juga terkandung minyak atsiri, ageconyflavone, dan ageratochromene. Batang mengandung resin, saponin, tanin, glikosida, dan flavonoid. Sementara di akar terdapat resin, alkoloid, saponin, dan flavonoid. [3]

Dari penelitian sebelumnya, menunjukan bahwa konsentrasi ekstrak etil asetat daun babadotan yang dapat memberikan efek penyembuhan yang sangat nyata (bermakna) pada luka terbuka yaitu pada konsentrasi $40 \%$ dan $80 \%$, sedangkan konsentrasi ekstrak babadotan 20\% tidak memberikan efek penyembuhan yang bermakna. Berdasarkan penelitian yang telah dilakukan diatas, penulis tertarik meneliti apakah ekstrak etanol daun Babadotan (Ageratum conyzoides L.) yang dibuat dalam sediaan salep dapat mengobati luka terbuka dan memiliki stabilitas yang baik serta mudah digunakan.

Untuk mengetahui sejauhmana efektivitas sediaan salep ekstrak etanol daun babadotan (Ageratum conyzoides L.), maka peneliti melakukan pengujian terhadap penyembuhan luka terbuka pada kelinci.

\section{METODE PENELITIAN}

Bahan: Bahan yang digunakan dalam penelitian ini meliputi ekstrak etanol daun babadotan (Ageratum conyzoides L), aquadest, etanol $70 \%$, vaselin album, adeps lanae, povidone-iodine, Pereaksi Mayer, Pereaksi Wagner, Pereaksi Dragendorff, Pereaksi Bucharat, $\mathrm{H}_{2} \mathrm{SO}_{4}$ pekat, $\mathrm{NH}_{3}, \mathrm{CHCl}_{3}, \mathrm{HCl}$ pekat, serbuk magnesium $(\mathrm{Mg}), \mathrm{FeCl}_{3}$ dan 3 kelinci jantan putih dengan berat badan 3-3.5 $\mathrm{kg}$.

Alat: Alat-alat yang digunakan dalam penelitian ini yaitu alat gelas, labu Erlenmeyer, batang pengaduk, blender, mortir dan stamper, plat tetes, sudip, waterbath, cawan porselen, kapas, kertas saring, kater (silet), pencukur bulu, kandang, penggaris, ayakan mess no.40, timbangan analitik, rotary evaporator dan wadah salep.

\section{Metode}

Preparasi Sampel

Sampel yang digunakan adalah daun babadotan (Ageratum conyzoides L). Sampel daun babadotan segar yang berwarna hijau dibersihkan atau disortasi, kemudian dicuci dengan air mengalir hingga bersih. Sampel daun babadotan dikeringkan dengan dianginanginkan selama 3-5 hari. Sampel dihaluskan dengan blender serta diayak dengan pengayak ukuran 40 mesh.

\section{Penentuan Kadar Air}

Pengerjaannya dilakukan dengan cara cawan porselin dikeringkan pada suhu $105^{\circ} \mathrm{C}$ selama 3 jam, kemudian didinginkan dalam desikator selama 30 menit dan ditimbang untuk mengetahui bobot kosong dari cawan. 
Sebanyak 2 gram sampel dimasukkan ke dalam cawan porselin dan dimasukkan ke dalam oven pada suhu $105^{\circ} \mathrm{C}$ selama 6 jam, kemudian didinginkan dan ditimbang kembali. Rumus perhitungan kadar air, sebagai berikut:

$$
\text { Kadar air }(\%)=\frac{a-b}{a} \times 100 \%
$$

$\mathrm{a}=$ bobot sampel sebelum pemanasan $(\mathrm{g})$

$\mathrm{b}=$ bobot sampel setelah pemanasan $(\mathrm{g})$

\section{Pembuatan Ekstrak Etanol Daun daun babadotan (Ageratum conyzoides $\mathrm{L}$ )}

Serbuk simplisia daun babadotan yang telah diayak sebanyak 100 gram dilakukan maserasi dengan menggunakan pelarut etanol $70 \%$, caranya yaitu dengan merendam serbuk simplisia selama $3 \times 24$ jam. Setiap 24 jam maserat disaring, kemudian ditambahkan lagi pelarut etanol $70 \%$ sampai 3 kali ulangan. Hasil maserasi kemudian dipekatkan menggunakan rotary evaporator pada suhu $60^{\circ} \mathrm{C}$ sampai diperoleh ekstrak kental daun babadotan.

Ekstrak kental yang diperoleh kemudian dihitung $\%$ rendemennya dengan rumus:

$$
\text { Rendemen }=\frac{\text { bobot ekstrak kental }}{\text { bobot serbuk }} \times 100 \%
$$

\section{Uji Fitokimia[4]}

a. Uji Alkaloid

Sebanyak $500 \mathrm{mg}$ sampel (ekstrak etanol $96 \%$, ekstrak etil asetat, dan ekstrak nheksan)ditambahkan $1 \mathrm{ml}$ asam klorida $2 \mathrm{~N}$ dan $10 \mathrm{ml}$ air, panaskan di penangas air selama 2 menit, dinginkan dan saring. Kemudian dibagi menjadi 3 tabung reaksi. Pada tabung pertama dimasukkan pereaksi Mayer, hasil dinyatakan (+) jika terbentuk endapan putih. Pada tabung kedua dimasukkan perekasi Dragendorff, hasil dinyatakan (+) bila terbentuk endapan merah jingga. Pada tabung ketiga dimasukkan pereaksi Wagner, hasil dinyatakan (+) bila terbentuk endapan coklat.

b. Uji Flavonoid

Sebanyak $500 \mathrm{mg}$ sampel (ekstrak etanol $96 \%$, ekstrak etil asetat, dan ekstrak nheksan)dilarutkan dalam $5 \mathrm{ml}$ air kemudian dipanaskan selama 5 menit setelah itu disaring. Filtrat ditambahkan serbuk magnesium serta $\mathrm{HCl}$ :etanol (1:1) dan amil alkohol. Hasil dinyatakan positif bila terbentuk endapan warna jingga hingga merah ungu.

c. Uji Saponin

Sebanyak $500 \mathrm{mg}$ sampel (ekstrak etanol $96 \%$, ekstrak etil asetat, dan ekstrak nheksan)ditambahkan $5 \mathrm{ml}$ akuades dalam tabung reaksi. Dikocok kuat-kuat, adanya saponin ditandai dengan terbentuk busa yang stabil.

d. Uji Tanin

Sebanyak $500 \mathrm{mg}$ sampel (ekstrak etanol $96 \%$, ekstrak etil asetat, dan ekstrak nheksan)direbus dengan $10 \mathrm{ml}$ akuades dalam tabung reaksi selama 5 menit, kemudian disaring. Filtrat ditetesi $\mathrm{FeCl}_{3}$ $1 \%$. Uji positif ditandai dengan munculnya warna hijau kecoklatan atau biru kehitaman.

\section{e. Uji Steroid}

Sebanyak $500 \mathrm{mg}$ sampel (ekstrak etanol $96 \%$, ekstrak etil asetat, dan ekstrak nheksan) ditambahkan etanol kemudian dipanaskan selama 2 menit. Ekstrakdisaring dalam keadaan panas kemudian filtrat diuapkan di waterbath sampai kering. Setelah kering ditambahkan $1 \mathrm{ml}$ dietil eter kemudian dihomogenasikan selanjutnya ditambahkan 1 tetes $\mathrm{H} 2 \mathrm{SO} 4$ pekat dan 1 tetes $\mathrm{CH} 3 \mathrm{COOH}$ anhidrat. Uji positif ditandai dengan munculnya warna hijau atau biru.

\section{Pembuatan Sediaan Salep}

Sediaan salep yang dibuat dalam dengan konsentrasi ekstrak daun babadotan yang berbeda-beda, yaitu 30\%, 35\%, 40\%, $45 \%$ dan $50 \%$. Dibuat sebanyak 10 gram dari masingmasing konsentrasi, dengan pemakaian 3 kali dalam sehari, untuk selama 8 hari pengamatan.

Proses pembuatan salep diawali dengan peleburan basis salep dilakukan pada lumpang panas $\pm 60^{\circ} \mathrm{C}$ sambil terus diaduk hingga mencair, setelah basis salep tersebut agak dingin, ditambahkan ekstrak daun babadotan sedikit demi sedikit dan terus diaduk hingga homogen dan membentuk salep.

\section{Evaluasi Sediaan Salep}

a) Evaluasi Fisik

Uji organoleptik pengujian dilakukan dengan mengamati sediaan salep dari bentuk, 
bau, dan warna sediaan (Anief, 1997). Uji homogenitas dilakukan untuk melihat bahanbahan dari sediaan salep tercampur dan tersebar menjadi homogen. Yaitu dengan cara salep dioleskan pada sekeping kaca atau bahan transfaran lain yang cocok, harus menunjukan susunan yang homogeny. [5]

b) Evaluasi Kimia

Sebanyak 0.5 g salep ektrak daun babadotan diencerkan dengan $5 \mathrm{ml}$ aquades, kemudian $\mathrm{pH}$ meter dicelupkan selama 1 menit, dan dilihat nilai $\mathrm{pH}$ nya pada monitor $\mathrm{pH}$ meter.

c) Uji Daya Sebar

Sebanyak 0.5 gram salep diletakan diatas kaca bulat, kaca lainya diletakan diatasnya dan dibiarkan selama satu menit. Diameter sebar salep diukur. Setelahnya, ditambah 100 gram beban tambahan dan didiamkan selama satu menit lalu diukur diameter yang konstan. [6]

\section{Pembuatan Luka}

Sehari sebelum pembuatan luka, hewan uji dicukur bulunya didaerah punggung sampai licin. Pada saat dibuat luka, terlebih dahulu daerah punggung dan sekitarnya dibersihkan dengan alkohol $70 \%$. Selanjutnya dibuat luka sayatan dengan ukuran panjang 1.5 $\mathrm{cm}$ pada bagian punggung dengan cara mengangkat kulit kelinci dengan pinset, kemudian dibuat luka dengan kater yang sudah disterilakn terlebih dahulu dengan alkohol $70 \%$, diuat luka sampai bagian subkutan kulit kelinci. Kemudian setiap luka pada kelinci diolesi dengan sediaan salep povidone-iodine, dan salep ekstrak etanol daun babadotan $30 \%$, $35 \%$, 40\%, $45 \%$ dan 50\%, masing-masing dioleskan secukupnya $3 \times 1$ sehari. [7]

\section{Uji Efektivitas Sediaan Salep Ekstrak daun Babadotan}

Pengujian efektivitas sediaan salep ekstrak daun babadotan (Ageratum conyzoides L.) dilakukan pada kelinci yang sudah dilukai dengan ukuran panjang 1.5 $\mathrm{cm}$, kemudian luka diolesi povidone-iodine (kontrol positif), tanpa perlakuan (kontrol negatif) dan salep ekstrak etanol daun babadotan 30\%, 35\%, 40\%, 45\% dan 50\%. Masing-masing dioleskan secukupnya pada luka, 3 x 1 sehari, Diamati luka yang sudah di olesi salep selama 8 hari.

\section{Analisa Data}

Pengukuran rata-rata panjang luka terbuka dilakukan sebanyak 3 kali pengulangan. Dihitung dengan rumus:

$$
\mathrm{dx}=\frac{d 1+d 2+d 3}{d} \text { untuk hasil pengukuran }
$$

panjang rata-rata luka $(\mathrm{cm})$ dari tiap hewan uji. Keterangan: d1, d2, dan d3 yaitu rata-rata luka setiap kali pengulangan perlakuan sedangkan d adalah banyaknya perlakuan. Secara statistik data dianalisis dengan metode ANOVA (Analysis Of Variant) dengan $\alpha 0.05$ atau 5\%, dengan rumus : $\frac{d 0 X d x}{d 0} \times 100 \%$.

\section{HASIL DAN PEMBAHASAN Simplisia}

Sampel yang digunakan pada penelitian ini adalah daun babadotan (Ageratum conyzoides L) Simplisia daun babadotan dibuat serbuk dan diayak dengan pengayak 40 mesh. Setelah pengayakan, serbuk daun babadotan diukur kadar airnya. Penentuan kadar air berguna untuk mengetahui batasan maksimal atau kisaran kandungan air dalam bahan. Hal ini berhubungan dengan daya simpan simplisia, sehingga jika melebihi batas yang ditentukan sangat mempengaruhi waktu kadaluarsa dari simplisia tersebut. Semakin tinggi kadar air, maka semakin mudah ditumbuhi jamur dan kapang sehingga dapat menurunkan aktivitas biologi senyawa aktif selama penyimpanan. Jumlah kadar air yang baik pada daun, yaitu $\leq 10 \%$. [8]

Hasil penetapan kadar air yang diperoleh pada penelitian ini adalah 6,6\% yang artinya kadar air ekstrak daun babadotan telah memenuhi persyaratan sehingga tidak mudah ditumbuhi jamur dan kapang, serta dapat disimpan dalam waktu yang cukup lama atakan kandungan zat dalam tumbuhan sebagai persen bahan kering.

\section{Hasil Ekstraksi Daun Babadotan}

Sampel daun babadotan diekstraksi dengan tujuan untuk memisahkan komponen kimia yang terdapat pada daun babadotan. Metode ekstraksi yang digunakan pada penelitian ini, yaitu maserasi dengan pelarut etanol 96\%. Penggunaan etanol sebagai pelarut disebabkan karena etanol bersifat polar sehingga dapat menarik senyawa-senyawa polar seperti flavonoid, saponin, tanin yang memiliki efektivitas terhadap penyembuhan 
luka terbuka. Pemilihan metode maserasi dikarenakan maserasi merupakan metode yang paling mudah dan sederhana, tidak memerlukan peralatan yang khusus serta suhu yang digunakan rendah sehingga dapat mencegah penguraian senyawa yang tidak tahan panas. Ekstrak yang diperoleh dari hasil ekstraksi ini dipekatkan dan dihasilkan ekstrak kental. Persen rendemennya adalah 2,29\%.

\section{Hasil fitokimia Ekstrak Etanol Daun Babadotan}

Uji fitokimia dalam penelitian ini dilakukan bertujuan menganalisis keberadaan

\begin{tabular}{|c|c|}
\hline Pengujian & $\begin{array}{c}\text { Ekstrak Daun } \\
\text { Babadotan }\end{array}$ \\
\hline Alkoloid & + \\
Flavonoid & + \\
Tanin & + \\
Saponin & + \\
Steroid & + \\
Terpenoid & + \\
\hline
\end{tabular}

Keterangan :(+) : Terdeteksi mengandung zat aktif

\section{Tabel 1. Hasil uji fitokimia dari simplisia dan ekstrak daun babadotan}

senyawa yang diduga memiliki aktivitas antikanker dalam ketiga ekstrak daun babadotan. Penapisan dilakukan terhadap golongan senyawa alkaloid, flavonoid, saponin dan tanin. dari hasil uji terlihat bahwa ekstrak daun babadotan mengandung alkaloid dengan intensitas warna rendah, tanin dengan intensitas warna tinggi. Hasil pengujian flavonoid, saponin dan steroid bahwa mengandung flavonoid, saponin dan steroid yang memiliki intensitas warna yang cukup tinggi.

\section{Hasil Uji Organoleptik}

Pengujian organoleptik yang dilakukan dengan mengamati sediaan salep ekstrak daun babadotan (Ageratum conyzoides $\mathrm{L}$ ) berdasarkan bentuk, warna, dan ba.

Tabel 2. Hasil Uji Organoleptik

\begin{tabular}{|c|c|c|c|}
\hline Jenis Salep & Bentuk & $\mathrm{Bau}$ & Warna \\
\hline $\begin{array}{c}\text { Kontrol Negatif } \\
\text { (Tanpa Penambahan Ekstrak) }\end{array}$ & Setengah Padat & Tidak berbau & Putih \\
\hline $\begin{array}{c}\text { Kontrol Positif (Povidone } \\
\text { Iodine 10\%) }\end{array}$ & Setengah Padat & Bau khas betadin & Coklat oren \\
\hline SEDB $30 \%$ & Setengah Padat & $\begin{array}{c}\text { Bau khas ekstrak daun } \\
\text { babadotan }\end{array}$ & Coklat muda \\
\hline SEDB $35 \%$ & Setengah Padat & $\begin{array}{l}\text { Bau khas ekstrak } \\
\text { daunbBabadotan }\end{array}$ & Coklat muda \\
\hline SEDB $40 \%$ & Setengah Padat & $\begin{array}{c}\text { Bau khas ekstrak daun } \\
\text { babadotan }\end{array}$ & Coklat muda \\
\hline SEDB $45 \%$ & Setengah Padat & $\begin{array}{c}\text { Bau khas ekstrak daun } \\
\text { babadotan }\end{array}$ & Coklat pekat \\
\hline SEDB $50 \%$ & Setengah Padat & $\begin{array}{c}\text { Bau khas ekstrak daun } \\
\text { babadotan }\end{array}$ & Coklat pekat \\
\hline
\end{tabular}

Keterangan (SEDB):Salep Ekstrak Daun

Babadotan 
Uji organoleptik sediaan salep ekstrak daun babadotan menunjukan bahwa ekstrak mempengaruhi warna dari sediaan. Salep ekstrak daun babadotan dengan basis vaselin album dan adeps lanae menghasilkan bentuk salep yang setengah padat, kemudian warna yang berbeda antara salep yang memiliki konsentrasi 30\%, 35\%, 40\% dengan salep yang memiliki konsentrasi $45 \%$ dan $50 \%$ tetapi semuanya memiliki bau khas ekstrak daun babadotan.

\section{Uji pH}

Tabel 3. Hasil Uji pH

\begin{tabular}{|c|c|}
\hline Jenis Salep & pH \\
\hline SEDB 30\% & 5.69 \\
\hline SEDB 35\% & 5.70 \\
\hline SEDB 40\% & 5.71 \\
\hline SEDB 45\% & 5.72 \\
\hline SEDB 50\% & 5.74 \\
\hline
\end{tabular}

Keterangan (SEDB):Salep Ekstrak Daun Babadotan

Uji $\mathrm{pH}$ yang dilakukan pada tiap konsentrasi salep ekstrak daun babadotan diperoleh nilai $\mathrm{pH}$ yang berbeda-beda. Pengujian $\mathrm{pH}$ dilakukan dengan menggunakan $\mathrm{pH}$ meter dan hasilnya bisa dilihat pada monitor $\mathrm{pH}$ meter. Salep ekstrak daun babadotan dengan konsentrasi yang berbeda-beda memiliki $\mathrm{pH}$ yang sesuai dengan kriteria $\mathrm{pH}$ kulit yaitu $4.5-$ 6.5 sehingga aman untuk digunakan, karena $\mathrm{pH}$ yang terlalu asam dapat mengiritasi kulit sedangkan $\mathrm{pH}$ yang terlalu basa dapat membuat kulit bersisik.

\section{Uji Homogenitas}

Tabel 4. Hasil Uji Homogenitas

\begin{tabular}{|c|c|}
\hline Jenis Salep & Homogenitas \\
\hline SEDB 30\% & $\begin{array}{c}\text { Homogen dan tidak } \\
\text { menggumpal }\end{array}$ \\
\hline SEDB 35\% & $\begin{array}{c}\text { Homogen dan tidak } \\
\text { menggumpal }\end{array}$ \\
\hline SEDB 40\% & $\begin{array}{c}\text { Homogen dan tidak } \\
\text { menggumpal }\end{array}$ \\
\hline SEDB 45\% & $\begin{array}{c}\text { Homogen dan tidak } \\
\text { menggumpal }\end{array}$ \\
\hline SEDB 50\% & $\begin{array}{c}\text { Homogen dan tidak } \\
\text { menggumpal }\end{array}$ \\
\hline
\end{tabular}

Keterangan :(SEDB) : Salep Ekstrak Daun Babadotan
Uji homogenitas setiap konsentrasi yang dilakukan memberikan hasil yang homogen yaitu dilihat berdasarkan tidak adanya gumpalan maupun butiran kasar pada sediaan salep ekstrak daun babadotan. Sediaan salep yang homogen mengindikasikan bahwa ketercampuran dari bahan-bahan salep serta ekstrak daun babadotan yang digunakan baik sehingga tidak didapati gumpalan ataupun butiran kasar pada sediaan . [9]

\section{Uji Daya Sebar}

Hasil pengukuran daya sebar dapat dilihat pada tabel 7. Dibawah ini

Tabel 5. Hasil Uji Daya Sebar

\begin{tabular}{|c|c|}
\hline Jenis Salep & Daya Sebar \\
\hline SEDB 30\% & 4.1 \\
\hline SEDB 35\% & 4.1 \\
\hline SEDB 40\% & 4.2 \\
\hline SEDB 45\% & 4.2 \\
\hline SEDB 50\% & 4.2 \\
\hline
\end{tabular}

Keterangan :(SEDB) : Salep Ekstrak Daun

Babadotan

Pengujian daya sebar pada setiap konsentrasi yaitu untuk mengetahui kemampuan sediaan salep ekstrak daun babadotan menyebar pada kulit. Sediaan salep yang nyaman digunakan memiliki daya sebar sebesar 5 sampai dengan $7 \mathrm{~cm} \mathrm{[10].} \mathrm{Dari} \mathrm{hasil}$ pengujian daya sebar menunjukan bahwa salep ekstrak daun babadotan yang dibuat belum memenuhi parameter daya sebar yang nyaman bagi kulit, tetapi salep ekstrak daun babadotan masih bisa digunakan, hanya saja akan terasa kurang nyaman (terasa tebal) dikulit. Hasil ini diduga disebabkan oleh konsistensi sediaan yang terlalu kental.[11] 
Hasil Pengamatan Penyembuhan Luka

Tabel 6. Hasil Pengukuran Panjang Luka Kelinci Hari ke-0 sampai Hari ke-8

\begin{tabular}{|c|c|c|c|c|c|c|c|c|c|c|}
\hline \multirow{2}{*}{$\begin{array}{l}\text { Kelompok } \\
\text { Perlakuan }\end{array}$} & \multirow[t]{2}{*}{$\begin{array}{l}\text { Pengula- } \\
\text { ngan }\end{array}$} & \multicolumn{9}{|c|}{$\begin{array}{c}\text { Panjang luka hari ke-0 sampai hari ke-8 } \\
(\mathrm{cm})\end{array}$} \\
\hline & & $\mathrm{H} 0$ & $\mathrm{H} 1$ & $\mathrm{H} 2$ & $\mathrm{H} 3$ & $\mathrm{H} 4$ & $\mathrm{H} 5$ & H6 & $\mathrm{H} 7$ & $\mathrm{H} 8$ \\
\hline \multirow{3}{*}{$\begin{array}{c}\text { Kontrol Negatif } \\
\text { (Tanpa } \\
\text { perlakuan) }\end{array}$} & 1 & 1.5 & 1.5 & 1.3 & 1.2 & 1.1 & 1 & 0.9 & 0.8 & 0.7 \\
\hline & 2 & 1.5 & 1.5 & 1.3 & 1.1 & 1 & 1 & 0.9 & 0.9 & 0.9 \\
\hline & 3 & 1.5 & 1.4 & 1.3 & 1.2 & 1.1 & 1 & 0.9 & 0.9 & 0.8 \\
\hline \multirow{3}{*}{$\begin{array}{c}\text { Kontrol Positif } \\
\text { (Povidone Iodine } \\
10 \%)\end{array}$} & 1 & 1.5 & 1.3 & 1 & 0.9 & 0.7 & 0.5 & 0.4 & 0.3 & 0.1 \\
\hline & 2 & 1.5 & 1 & 0.9 & 0.7 & 0.6 & 0.5 & 0.3 & 0.1 & 0.0 \\
\hline & 3 & 1.5 & 1.3 & 0.9 & 0.8 & 0.6 & 0.5 & 0.4 & 0.3 & 0.0 \\
\hline \multirow{3}{*}{ SEDB 30\% } & 1 & 1.5 & 1.4 & 1.2 & 1 & 0.9 & 0.8 & 0.6 & 0.5 & 0.2 \\
\hline & 2 & 1.5 & 1.3 & 1.2 & 1 & 0.9 & 0.9 & 0.8 & 0.7 & 0.5 \\
\hline & 3 & 1.5 & 1.4 & 1 & 0.9 & 0.8 & 0.8 & 0.7 & 0.5 & 0.3 \\
\hline \multirow{3}{*}{ SEDB 35\% } & 1 & 1.5 & 1.4 & 1 & 0.9 & 0.8 & 0.7 & 0.6 & 0.4 & 0.1 \\
\hline & 2 & 1.5 & 1.3 & 1.1 & 1 & 0.9 & 0.9 & 0.7 & 0.6 & 0.4 \\
\hline & 3 & 1.5 & 1.4 & 1 & 0.9 & 0.8 & 0.8 & 0.7 & 0.7 & 0.6 \\
\hline \multirow{3}{*}{ SEDB $40 \%$} & 1 & 1.5 & 1.3 & 1 & 0.9 & 0.7 & 0.6 & 0.5 & 0.3 & 0.0 \\
\hline & 2 & 1.5 & 1 & 0.9 & 0.8 & $\overline{0.6}$ & 0.5 & 0.4 & 0.3 & 0.2 \\
\hline & 3 & 1.5 & 1.3 & 1 & 0.9 & 0.8 & 0.7 & 0.6 & 0.4 & 0.1 \\
\hline \multirow{3}{*}{ SEDB $45 \%$} & 1 & 1.5 & 1.3 & 0.8 & 0.8 & 0.6 & 0.5 & 0.4 & 0.2 & 0.0 \\
\hline & 2 & 1.5 & 1 & 0.9 & 0.8 & 0.6 & 0.5 & 0.4 & 0.3 & 0.1 \\
\hline & 3 & 1.5 & 1.3 & 0.9 & 0.7 & 0.6 & 0.5 & 0.4 & 0.2 & 0.0 \\
\hline \multirow{3}{*}{ SEDB 50\% } & 1 & 1.5 & 1.3 & 1 & 0.7 & 0.5 & 0.4 & 0.3 & 0.0 & 0.0 \\
\hline & 2 & 1.5 & 1 & 0.8 & 0.7 & 0.5 & 0.4 & 0.3 & 0.1 & 0.0 \\
\hline & 3 & 1.5 & 1 & 0.8 & 0.7 & 0.5 & 0.4 & 0.3 & 0.1 & 0.0 \\
\hline
\end{tabular}

Keterangan :

SEDB : Salep Ekstrak Daun Babadotan

Hasil pengukuran panjang luka terhadap proses penyembuhan luka terbuka pada kelinci putih jantan dengan berat $3-3.5 \mathrm{~kg}$ selama 8 hari. Pengukuran panjang luka untuk semua kelompok perlakuan pada hari ke-1 sampai hari ke-8 mengalami perubahan. Pada hari ke-0 untuk semua kelompok perlakuan masih terbuka dan belum terlihat adanya perubahan karena belum diberi perlakuan, untuk hari ke-1 perubahan sedikit terlihat sedangkan pada hari ke-6 tepi luka untuk semua perlakuan mulai menyempit sedangkan penyembuhan yang signifikan terlihat pada hari ke-7 dimana luka tertutup sempurna yaitu pada sediaan salep ekstrak daun babadotan (SEDB) $50 \%$, jika dibandingkan dengan kelompok perlakuan lainnya. Artinya didalam salep ekstrak daun babadotan mengandung zat aktif yang mampu salep yang memiliki konsentrasi $40 \%$ dan $45 \%$. Hal ini disebabkan karena

semakin bertambahnya konsentrasi ekstrak daun babadotan, maka semakin cepat waktu yang diperlukan untuk penyembuhan luka.

Berdasarkan analisis dengan dengan ANOVA, p-value respon pada hari ke-2 sampai hari ke-8 lebih kecil dari alpha 5\% artinya perlakuan berpengaruh terhadap respon mulai dari hari ke-2 sampai hari ke-8. Sedangkan pada hari ke 0 dan ke-1 perlakuan belum terlihat pengaruh perubahan penutupan luka.

\section{SIMPULAN}

Hasil penelitian menunjukkan bahwa pemberian formulasi salep ekstrak daun babadotan memenuhi persyaratan kualitas salep yaitu uji organoleptik, uji homogenitas, uji $\mathrm{pH}$ dan uji daya sebar. Salep ekstrak daun babadotan konsentrasi 30\% dan 35\% tidak memberikan efek penyembuhan penutupan luka yang cepat. Salep ekstrak daun babadotan dengan konsentrasi $40 \%, 45 \%$ dan $50 \%$ 
memberikan efek penyembuhan terhadap luka terbuka pada kelinci, efek yang hampir mirip dengan kontrol positif (povidone iodne) sedangkan salep ekstrak daun babadotan yang memberikan efek paling baik yaitu salep dengan konsentrasi $50 \%$.

\section{SARAN}

Perlu dilakukan uji stabilitas dan sterilitas pada salep ekstrak daun babadotan untuk pengembangan produksi.

\section{DAFTAR PUSTAKA}

[1] BPOM RI. 2007. Acuan Herbal Indonesia. Volume ketiga edisi pertama. Jakarta. Badan POM RI

[2] Departemen Kesehatan RI. (1989). Materia Medika Indonesia. Jilid V. Jakarta: Depkes RI. Hal. 15

[3] Duryatmo, S dkk. 2010. Herbal Indonesia Berkhasiat Bukti Ilmiah dan Cara Racik. Edisi 2. Bogor: Turubus Swadaya

[4] Harborne, 1996. Metode Fitokimia Penuntun Cara Modern Menganalisis Tumbuhan. Terbitan kedua. Terjemahan K. Padmawinata dan 1. Soediro. Bandung: ITB.

[5] Anief, 1997. Ilmu Meracik Obat. Gadjah Mada University Press: Yogyakarta

[6] Astuti I. Y., D. Hartanti, dan A. Aminiati.2010. Peningkatan Aktivitas Antijamur Candida albicans Salep Minyak Atsiri Daun Sirih (Piper bettle LINN.) melalui Pembentukan Kompleks Inklusi dengan $\beta$ siklodekstrin.Majalah Obat Tradisional. 15: 94-99
[7] Hamzah, H., Fatimawali., Yamlean, P.V.Y., Mongi, J. 2013. Formulasi Salep Ekstrak Etanol Daun Nangka (Artocarpus heterophyllus Lam.) dan Uji Efektivitas Terhadap Penyembuhan Luka Terbuka pada Kelinci [Jurnal]. Manado: Program Studi Farmasi, FMIPA UNSART Manado

[8] Meyer, B. N., Ferrigni, N. R., Putman, J. E., Jacbsen, L. B., Nicols, D. E., and McLaughlin, J. L. 1982. Brine Shrimp : A Comvenient general Bioassay For Active Plant Constituents. Plant Medica, 45, $31-45$.

[9] Naibaho, O.H., Yamlean, P.V.Y., Wiyono, W. 2013. Pengaruh Basis Salep terhadap Formulasi Sediaan Salep Ekstrak Daun Kemangi (Ocimum sancum L.) pada Kulit Punggung Kelinci yang Dibuat Infeksi Staphylococcus aureus [Jurnal]. Manado : Program Studi Farmasi, FMIPA UNSART Manado.

[10] Grag, A et al. 2002. Spreading of Semisolid Formulation : An Update. Pharmaceutical Technology. 2002 : 84-104

[11] Parwanto, M.E.,Senjaya, H., Edy, H.J. 2013. Formulasi Salep Antibakteri Ekstrak Etanol Daun Tembelekan (Lantana camara L.) [Jurnal]. Jakarta : Fakultas KedoKedokteran Universitas Trisakti dan Manado : PS. Farmasi F-MIPA UNSRAT Manado. 